\title{
Marriage as A Reward for Disney Princesses
}

\author{
Ivena \\ English Department, Faculty of Letters, Petra Christian University, Surabaya, East Java, Indonesia \\ e-mail:m11414013@john.petra.ac.id
}

\begin{abstract}
This study focuses on the animations of three Disney princesses which are Snow White, Cinderella, and Aurora. Its goal is to find the meaning of marriage for the princesses that happen in the animations. The theories that are used for this study is the ideology of patriarchy, "Angel in the House" concept, and "Damsel in Distress" concept, which affect the characters in the animations. From the analysis, the marriage means a reward for the trio after they have suffered in order to reach perfection. By following the process according to the rule of patriarchy, the trio manages to become the ideal women and are given reward in the form of marriage. Thus, through their animations, Disney wants to show the audience about the ideology of patriarchy
\end{abstract}

Key words: Disney, Princess, Patriarchy, Marriage, Reward, Suffering.

\section{INTRODUCTION}

The success of Disney in producing Mickey Mouse and friends, lead them to create their new animations which now is known as Disney Princess. They manage to create eleven heroines to the Disney Princess lineup until 2018. They are Snow White, Cinderella, Aurora, Ariel, Belle, Jasmine, Pocahontas, Mulan, Tiana, Rapunzel, and Merida. There are several reasons why I choose Disney Princess for my analysis. First is because of their success and popularity among both adults and children. During the opening night of Snow White and the Seven Dwarfs in Carthay Circle Theatre in Los Angeles, the tickets were sold out with more than thirty thousand audiences, including celebrities like Charlie Chaplin and Shirley Temple (Glover, Erin; 2011). Another proof of Disney's success is their remake version of a fairy tale based from a book called Beauty and the Beast. Walt Disney Pictures co-produced the adaptation from the animated series to the live-action. People who grew up with the animated version gave a long wait for the adaptation. The movie received $\$ 165$ million just for the opening at the Box Office. Disney's attempt in remaking the classic tale into their own version is considered as successful because nowadays people recognize Disney's version than the original version of the tale. Rapunzel, a German fairy tale first made by Friedrich Schulz in 1790, was adapted by Brothers Grimm.

Disney Princess gives a very great impact to the children. Besides the fun sing-along in the movies, children like to learn the moral lessons from the movies. Some morals that they give to the audience is based on the Bible, for Walt Disney himself was a Christian. For example, Snow White is believed to be a Christian as she is seen praying before she sleeps. Another example is taken from one of the most famous Disney animated movies, Frozen, which is seen as a Christian-themed movie. It is acknowledged by Collin Garbarino, who is an assistant professor of history at Houston Baptist University. He sees Anna as a figure like Christ who tries to save her sister, Elsa, despite the rejection.

Children see the heroines as their role models for they are able to learn from their surroundings. For example, in Cinderella, children can learn about having faith that their dreams will come true. Through the song "A Dream is A Wish Your Heart Makes", it illustrates that Cinderella has hope until the appearance of her Fairy godmother who does 
the magic (Ellorin, Angie; 2015). Besides, children, mostly young girls, who watch Disney's animated series of the princesses will most likely to get "princess culture". The impact from Disney Princess makes children idolize the princess and wish to become like them. A research by Brigham Young University (BYU) family life professor, Sarah Coyne, tells about the impact from the animations. From 198 preschoolers, they are evaluated in how much they interact with Disney Princess culture, can be in the form of watching the movies or playing with the toys. The result shows that 96 percent of girls and 87 percent of boys get the Disney Princess culture. In addition, more than 61 percent of girls play with the princess toys at least once a week (McBride, Jon; 2016). This explains that children do not only get affected from the media they interact with, but also they are most likely to grow up with gender stereotypes. For girls, they mostly want to become pretty and act like a princess. Moreover, they wish for a man to come into their life, fall in love at the first sight, get married, and live happily ever after.

The effect from Disney's princess animated series that always shows the princess gets married (even some do not have wedding scene) and lives happily ever after is what makes me want to find the reasons. What intrigues me to analyze the animations is that the heroines always end up getting married. Apart from eleven official princesses, I choose to analyze the first three of Disney Princess which are Snow White, Cinderella, and Aurora. The reason why I choose only those three princesses besides their fame is because the others do not really talk about having a happy ending by marriage or being saved by the hero, which I want to analyze for my study. I want to know what the reason behind their marriage is or what makes them able to get married with the princes. The first generation of Disney Princess presents the topic for my study very well. Meanwhile, other princesses have evolved within the time and they do not have the same characters or personalities like the first ones. For example, Belle from Beauty and the Beast is not included for my study because she is the heroine who saves the man first, not the opposite like Cinderella. Other Disney princesses show a very different personality as they go on with the society, like feminism in Brave which shows that Merida does not need a man. They are considered as the nowadays Disney princesses who have outspoken personality (Manduke, Joseph; 2015). The trio has the same pattern or cycle of life, which are consisted of suffering and a happy ending. All of them end up in getting married with the men (princes) they meet and are described "and they live happily ever after". It is intriguing me to know what the marriage means to them after they have lived in such miserable life and they are able to get the "happily ever after". So, in this research, I want to know what is the meaning of marriage for the princesses from Disney's animations in Snow White and the Seven Dwarfs, Cinderella, and Sleeping Beauty. The purpose of this study is to show that the marriage is seen as a reward for the princesses.

In order to find answers of my statement, I use the ideology of patriarchy to analyze the meaning of marriage in the animations. This ideology will help me to analyze the princesses in getting married and living a happy life with the help of the princes. The patriarchal concept becomes the base of my theory and leads to other two secondary theories in analyzing the movies, which are the "Angel in the House" poem and "Damsel in Distress" concept.

Patriarchy is an ideology comes from the Greek since long time ago. It is seen to be the social system in the society. The word "patriarchy" itself is a compound from "patria" which means lineage, "pater" as father, and "archy" (arche) as "I rule". This ideology explains where man or father will be the one who rules and become dominant over everything (O'Reilly, 2010). Patriarchy has become the social system to put man as the one who has more power than woman. Men are seen as the ones who make decisions in every aspect and women should follow. They have the power to control women and women are dependent to men. Men see themselves as someone superior and women are their properties. 
Friedrich Engels (1884) divides the labor between men and women. He believes that men's job and women's job are different. Engels argues that:

The man fights in the wars, goes hunting and fishing, procures the raw materials of food and the tools necessary for doing so. The woman looks after the house and the preparation of the food and clothing, cooks, weaves, sews. They are each master in their own sphere: the man in the forest, the woman in the house. Each is owner of the instruments which he or she makes and uses: the man of the weapons, the hunting and fishing implements; the woman of the household gear (Engels, 1884).

The ideology of patriarchy shows that men always take control of everything, making themselves to work the "hard" work and give the easy part to women. The purpose of a woman is no other than to become a mother and bear a child. Besides that, women are seen as men's property or possession according to Nietzsche. "He must conceive of woman as a possession, a property that can be locked, as something predestined for service and achieving her perfection in that." (Diethe, 1996). This means that women are seen as men's possession where she must fulfill her duty to serve men in order to reach perfection to become a woman. Women will feel that they are fully themselves or feeling complete and perfect when they are able to do their duty, which is to serve men. Because women's duty is revolving in cleaning the house and taking care of the children, they have the personality of being kind and loving. Besides that, they must be well-behaved and stay devoted to their husbands. According to Nietzsche (Diethe, 1996), this is their way to become the perfect women in the patriarchy. Even though they are seen as inferior, weak, and submissive, women manage to stay devoted and nurturing to others.

The first secondary theory that I use to elaborate the meaning of marriage is the concept of "Angel in the House". It is a poem by Coventry Patmore to show how a perfect woman should be. Though the ideal woman is his own wife, the concept applies not only for wives, but also for unmarried women. The term "angel" explains that a woman or a wife should be like an angel who is kind and helpful to others. A woman should be charming, graceful, self-sacrificing, and powerless. Above all, a wife should be devoted to her husband and submissive. They have to please the husband no matter what.

Man must be pleased; but him to please (line 1)

She leans and weeps against his breast, (line 15)

And seems to think the sin was hers; (line 16)

The poem explains the concept of how a woman should act since the beginning, that she has to please the man. From the piece of the poem above, it is shown that men are the ones who are pleased, not the ones who please. They have more power that they are the ones who are served and women are the ones who should serve. A wife will be the one to take the fault of her husband. Even though it is not her fault, she puts herself to take the blame.

The second secondary theory that I use to help me in analyzing the animations is the "Damsel in Distress" concept. The concept comes from the ancient Greek and has become a classic theme in literature, more likely in fantasy genre. The word "damsel" itself means a young lady or maiden, which comes from the French demoiselle. "In distress" explains the situation of someone who is in pain or in trouble. The concept tells about a young lady who is in trouble and needs someone or a hero to rescue her. The beautiful maiden is always portrayed by having a passive personality. She is illustrated by being clueless and dependent on others to save her from her misery. Usually, the explanation of this concept is about a princess who is captured and a prince will come to rescue her. The prince will kill the enemy, mostly in the form of a dragon and later on the prince will marry the princess.

This secondary theory relates with the ideology of patriarchy because it tells about the superiority or the domination of men or husband. Men have more power and are allowed 
to do anything while women must put themselves lower. The concept of "Damsel in Distress" has a relation with the domination of men towards women. It explains how men, pictured as the hero, save the damsel. Women are explained in being weak and unable to save herself and needs men to save their lives.

Both secondary theories are based from the patriarchal concept as they have similar definitions about women. "Angel in the House" concept and "Damsel in Distress" both illustrate women as being inferior, weak, and submissive. The concept of "Angel in House" defines that a lady must have a self-blaming and self-sacrificing personally. Her duty is to please her man. However, she is not aware that her submissive personality makes her feel inferior. Meanwhile, the concept of "Damsel in Distress" has a slight difference from the latter. This classic theme describes a damsel who is helpless and needs a hero to save her. She is aware of her condition that she is in distress. Both concepts are considered as complementary as they have the same foundation from the ideology of patriarchy.

\section{MARRIAGE AS A REWARD}

The marriage happens after the trio suffers from their hardships, which include being mistreated, being chased, and being controlled. Snow White, Cinderella, and Aurora are known to be the miserable princesses because they have been suffering throughout their lives. Snow White is a born princess but suffers from her own stepmother who wants to kill her. Cinderella is a maiden who serves her stepfamily in her own house. Aurora is isolated from everyone, including her parents, because she is cursed. They have the same similarities where they do not live happily and are treated badly by their family. In the movies, the princesses are always seen doing household works, being mistreated and finally getting married to the princes who saved them from their miserable life. The marriage is seen as a reward for them after living in such a pitiful life. The suffering that they receive, which makes them deserve a reward, is because of the patriarchal concept, like becoming the angel and the damsel. They manage to become the good women according to the ideology of patriarchy throughout their suffering, which leads them deserve to be rewarded in the end. On the other hand, those who do not do their job in being the perfect woman like in the patriarchal concept, will be punished.

\section{Reward for Cinderella}

Cinderella is the only character in Cinderella who is rewarded also by the patriarchal ideology. Her reward comes in the form of marriage where she is able to get married with the prince and live in the castle. However, before her happy ending, Cinderella has gone through a lot of sufferings by her own family. The suffering that she goes through is a part of the concept, which is the ideology of patriarchy. The domination from the ideology is seen from Cinderella's personality in dealing with her stepfamily in the role of the "Angel in the House".

The hardship that Cinderella receives from her stepmother and stepsisters happens because of the ideology of patriarchy which works on her. The fact that she lets her family mistreat and abuse her hints on how the rule of patriarchy works, where she must not rebel and must be self- sacrificing. In her life with her stepfamily, the rule of patriarchy shows that she is the one who is in charge in doing the household chores. Cinderella is the one who is always seen cleaning the house and taking care of the family members. She fills Engels' division labor as the woman where she stays at home and cleans the house. The routine that she does daily shows the role of "mother" or woman in the family.

Cinderella also plays the role of the angel in own house where she puts the image of a lady who is graceful and self-sacrificing. Her personality is shown everyday through the way she responds to her rude stepsisters. Even if Cinderella becomes the angel where she 
cannot stand for herself, the role makes her suffering worse. However, she will be rewarded for being the "angel" in the house later on. For example, it happens when Anastasia blames her for putting a mouse under her teacup and the stepmother decides to give her punishments. Cinderella plays her role of being good-hearted and self-sacrificing where she takes the risk of being blamed, which shows how the rule of patriarchy works on her.

CINDERELLA You don't think that I ...

STEPMOTHER Hold your tongue.

CINDERELLA (Stop)

STEPMOTHER Now (pause) it seems we have time on our hands.

CINDERELLA But I was only trying to ...

STEPMOTHER Silence! Time for vicious practical jokes. Perhaps we can put it to better use. Now, let me see ... There's the large carpet in the main hall. Clean it! And the windows, upstairs and down. Wash them! Oh, yes. And the tapestries and the draperies.

CINDERELLA But I just finished ...

STEPMOTHER Do them again!

The dialogue above shows Cinderella's passive and helpless personality. Her patience towards the stepmother proves that she is playing the role of the "angel". Her benevolent personality makes her take the blame and accept whatever punishment that the stepmother gives. This moment shows how Cinderella suits the concept of "Angel in the House" as she has shown the image of being graceful, passive, and self-sacrificing.

The role of the "Damsel in Distress" is also played by Cinderella when the prince searches for her. She suffers because of the mistreatment from her harsh stepmother and stepsisters. Yet, Cinderella remains helpless and passive where she only hopes for her happiness and a better life. Since the announcement is spread, that anyone who fits the glass slipper will marry the prince, Cinderella does not have any worry anymore. She is seen to give the clothes to her stepsisters, to dance by herself in the hall, and to prepare herself to meet the prince. Her expression indicates that she already feels happy that the prince will come to rescue her from her abusive stepmother and stepsisters. Her action illustrates the damsel in distress who only waits for her hero to come. Cinderella plays herself as the damsel who will be saved by her prince and will live together with him. The prince becomes her hero who saves her from her distress through the duke who visits Cinderella's house. Cinderella's suffering is ended by her getting married with the prince. Her happy ending is held by the prince because without his help, Cinderella would not be able to receive her reward.

On the opposite side, Cinderella's stepmother and stepsisters are never seen to become the ideal ladies according to the patriarchal concept. Instead, they are presented to be the wicked ones who abuse Cinderella. For example, they let Cinderella to work on the household chores, which is actually something that they also should do as women. The way they speak and act are completely different from how a woman should be in Patmore's poem. The stepmother and stepsisters are seen as wicked and selfish, which is shown through the way they treat Cinderella every day. For example, the stepmother's wicked personality is illustrated through her ambition in getting one of her daughters to marry the prince. The fact that she uses dirty trick by locking Cinderella and making the duke breaks the slipper proves that her personality is far from how Patmore describes the perfect woman or wife. This results to them receiving a sanction where they have to live in dirty surroundings and suffer. (seen in Cinderella 3: A Twist in Time). 


\section{Reward for Snow White}

Snow White is one of the Disney princesses who is chosen as the representative of woman because she illustrates how the rule of patriarchy must be done. Despite her miserable life, in which she is chased by her own stepmother who wants to kill her, she manages to endure her agony. She is able to become the example of the one who reaches perfection during her misery until she is rewarded by meeting again with the prince. The misery that Snow White goes through makes her become the "damsel in distress". She is defenseless and unable to save herself because of the rule of patriarchy where women must not be active and wait to be rescued by men.

Snow White's life has been full of difficulty since the beginning of the story. Her own stepmother, the Evil Queen hates her and treats her like a scullery maid. Despite all of the humiliation, Snow White displays the patriarchal concept where she knows a woman must be obedient and tender-hearted. The concept of "Angel in the House" also fits perfectly in Snow White and the Seven Dwarfs where Snow White is shown as the ideal woman. The perfect woman is described to be innocent, kind and obedient. Snow White has all the traits to become the angel in her own castle which can be seen through the way she acts and speaks. Though she is treated as a maid, Snow White has never once complained. Her role in becoming the "Angel in the House" shapes her personality to be generous and forgiving towards her stepmother's cruelty. The ideology of patriarchy where it teaches women to be devoted and lenient dominates Snow White's mindset, which makes her always be wellbehaved and never rebel.

In Snow White and the Seven Dwarfs, the labor division of Engels is presented very clearly through what Snow White does for the dwarves. Snow White shows the example of what women must do which is taking control of the household chores. This ideology of patriarchy indicates the domination where men are the ones who are in charge of the field and women's job is only in the house.

SNOW WHITE
And just look at that fireplace. It's covered with dust. And look, cobwebs everywhere! My, my, my! What a pile of dirty dishes! And just look at that broom! Why, they've never swept this room! You'd think their mother would ... (gasp) Maybe they have no mother. Then they're orphans. That's too bad. I know! We'll clean the house and surprise them! Then maybe they'll let me stay.

Snow White expresses concern when she enters the dwarves' house and keeps on making comments on how dirty the house is. The fact that she cannot bear to see the dirty surroundings and chooses to clean it proves that Snow White believes that women are the ones who do the household chores, so it is natural for her to show concern towards the dirty place. Meanwhile, the scene where the dwarves are working shows Engels' labor division is true for men are the ones who go out working. The surprised dwarves after they see the clean cottage also prove that men are considered to be natural to be related with being dirty. For Snow White, cleaning the house, cooking, and setting up the table are things that she has been doing to serve others just like in "Angel in the House" where women are the ones who serve, not men. The one who is in charge of household chores must be women. The fact that Snow White voluntarily starts to clean the house proves that the rule of patriarchy where women must be in control of the house works on her.

The patriarchal concept also teaches women to place themselves lower than men. They do not put their place above men for they have to be docile and obedient. They are not 
allowed to be demanding despite the status they have. It is shown through Snow White's negotiation with the dwarves when she seeks shelter. Snow White who bargains with the dwarves despite her status of being the princess proves the domination of the patriarchal concept where it puts women on the second level. Snow White actually has the authority to demand the dwarves to let her stay because of her status. Instead, she begs for their approval to stay at the cottage. This proves that the ideology of patriarchy is running in Snow White's mind for she knows that a woman is not allowed to be demanding. Despite her status of being the princess where she can take control of the dwarves, she lowers herself to become well-behaved and humble in front of them. She lets the dwarves decide her fate, whether she stays or leaves. This example indicates the patriarchal concept where men have more control than women. Though this moment shows how helpless Snow White is, it makes her become the absolute type of woman.

The "Damsel in Distress" concept suits in the plot of Snow White and the Seven Dwarfs. It is explained in the ending scene where Snow White wakes up after the prince kisses her and she is taken to his castle. Through the prince's action in saving Snow White, the ideology of patriarchy is also illustrated in that moment. In the end, men are the ones who will save women because they are seen as stronger. Snow White, who shows the example of how the rule of patriarchy works, always portrays how an ideal woman must be weak and dependent on others.

Snow White finally obtains a prize after her long suffering and miserable life. Her final reward is given through her marriage with the prince where she is able to live happily. The gift that she receives is the result of her being the complete example of how the women in the rule of patriarchy should be. She understands that a woman must be generous at all times, self-sacrificing, lenient, and must wait to be rescued. Because she endures her hardship while tries to become the ideal woman, it makes Snow White deserves to be rewarded. On the other hand, Snow White's stepmother, who is seen as someone wicked and evil, gets no reward at all. Instead, she pays for the price where she falls to her own death.

\section{Reward for Aurora}

Sleeping Beauty represents the concept of the "Damsel in Distress" through their princess, Aurora. The patriarchal concept is illustrated by the hands of how the main character shows her personality and respond to treatment from others. Aurora is shown to be clearly being influenced by the ideology of patriarchy from her parents and this leads to her suffering in the movie at the beginning. Although she is controlled and isolated from everyone, she manages to act according to how women in patriarchal concept do.

After Aurora is cursed and isolated from everyone except from the fairies, her lack of freedom is shown during that moment. Despite her condition, she manages to play the role as an angel. The sixteenth-year-old Aurora is seen to clean the window and pick the berries. Another example that Aurora is the angel in her own house is when the fairies tell her to go out because they are preparing a surprise party for her. Aurora actually knows that the fairies are planning something, but she chooses to obey them when they tell her to go out. This shows Patmore's description of an ideal woman who must be obedient and gentle. After the fairies tell Aurora that she is not allowed to meet the man in the wood, not realizing that it is Prince Philip, Aurora does not even get angry or yell at them. She only shows her disbelief and cries in her room. This action fits the concept as she does not even rebel to the fairies, like in the poem which written "While she, too gentle even to force;" (line 9). This poem fits Aurora's response towards her aunts. She is too kind and passive to even get angry and let the fairies allow her to meet the prince. This is why Aurora is considered to be the perfect woman as she has the personality of Patmore's description. 
Aurora plays the role as the damsel in the "Damsel in Distress" concept together with Prince Philip, who plays as the hero. Since Aurora is cursed, her life has been miserable because she is isolated and controlled by others. However, since she acts like an angel, she does not even try to free herself. She keeps on being passive and hopes that one day someone will save her. She cannot save herself and depends her life on others, just like how Maleficent traps her. In the end, her life is saved by Prince Philip who becomes her hero. The concept of "Damsel in Distress" presents the image of women who are always helpless and need men to save them. Aurora shows the image of women who are weak and helpless who is saved by Prince Philip who presents the image of men who are seen as stronger and powerful.

Sleeping Beauty also gives an example of a woman who does not follow the rule of patriarchy like Aurora. While a woman must be obedient and devoted despite all conditions and trouble around her, the antagonist in the animation is illustrated by being selfish and ambitious. Maleficent, the evil fairy, is represented as the antagonist who does not try to become the dream- like woman. Her death is a proof that if one does not follow the patriarchy concept, she will be punished instead of rewarded.

The patriarchal concept, with the complementary concepts, is seen to be applied in the three animations above. The trio is portrayed to have a passive, submissive, and weak personality. They are aware that their duty is to take care of the house and family. In addition, they also put themselves in a lower position than men, despite their status. The nature that they have are based from the patriarchal concept. Through their inferiority, the trio manages to finish their process in becoming the ideal women according to the rule of patriarchy. As they have finished their goal in reaching perfection, they deserve to get a reward. Their reward comes in the form of marriage with the prince where later on they will gain their happy ending.

\section{CONCLUSION}

This study discusses the meaning of marriage that happens in Disney's animations. The trio, Snow White, Cinderella, and Aurora, are the subjects of this analysis. Throughout the movies, the princesses are shown to encounter the princes in a very short time. Despite that, the trio manages to get married with them and is given a happy ending after their long, miserable life. From the analysis, I found out that the meaning of the princesses' marriage is a reward for them. Snow White, Cinderella, and Aurora are seen to endure all sufferings, which is a part of their process in the rule of patriarchy. The marriage is a reward for them after becoming the standard woman in patriarchal society. Therefore, the "promised happiness" that is presented in Disney's animations can be achieved by becoming the woman according to the patriarchal concept. In addition, the ideology of patriarchy does not promise a happy ending for those who do not follow their rule.

In conclusion, Snow White, Cinderella, and Aurora get their "happily ever after" after their misery. Before they get their happy ending, the trio has gone through their sufferings as a part of their process to reach perfection. In order to become perfect, they must be kind, obedient, submissive, and self-blaming personality, which are the traits of the women in the patriarchal concept. Disney portrays a woman's duty must be at home, taking care of her family and the household. Since they manage to endure their hardship and finish their process, they are given a reward by the ideology of patriarchy. Through the animations, the reward is given in the form of marriage with the prince. The trio's stories end with a happy ending since they reach their perfection and their lives are changed through their marriage. Disney might also illustrate that women is obligated to get married and receive their happy ending. To add, for those who are not able to become the dream-like women like the trio will receive their punishment. 


\section{REFERENCES}

Chong, A. (2007). Basics animation 02: Digital animation. Worthing, UK: AVA Publishing. Diethe, C. (1996). Nietzsche's women: Beyond the whip. Berlin: Walter de Gruyter.

Ellorin, A. (2015, March 20). Why the disney princesses are good role models. Her Campus. Retrieved from $<$ https://www.hercampus.com/school/vcu/why-disney-princesses-are-good-rolemodels $>$

Engels, F. (1884). The origin of the family, private property and the state. London, England, UK: Penguin Books.

Glover, E. (2011, December 21). Opening night, 1937: 'Snow white and the seven dwarfs' premieres at carthay circle theatre. Retrieved from $<$ https://disneyparks.disney.go.com/blog/2011/12/opening-night-1937-snow-whiteand-the-seven-dwarfs-premieres-at-carthay-circle-theatre/>

Hekman, S. J. (1990). Gender and knowledge: Elements of a postmodern feminism. Boston, MA: Northeastern.

Lee, M. (2011, January 21). Tangled directors on the latest Disney Animation. The Telegraph. Retrieved from $<$ http://www.telegraph.co.uk/culture/film/filmmakersonfilm/8287107/Tangleddirectors-on-the-latest-Disney-animation.html $>$

Lerner, G. (1993). Women and history 2. Oxford, England, UK: Oxford University Press.

Manduke, J. (2015, July 13). Feminism and the disney princesses. The Artifice. Retrieved from $<$ https://the-artifice.com/feminism-disney-princesses/>

McBride, J. (2016). Disney Princesses: Not Brave Enough. Retrieved from Brigham Young University website:

$<$ https://news.byu.edu/news/disney-princesses-not-brave-enough $>$

n.n. (2011, March 2). The Angel in the House. Retrieved from Brooklyn College website: $<\mathrm{http}$ ://academic.brooklyn.cuny.edu/english/melani/novel_19c/thackeray/angel.htm $1>$

O'Reilly, A. (2010). Encyclopedia on motherhood. California, United States: SAGE Publications Inc.

Pinsky, M. (2014, January 25). Disney's frozen might be the most Christian movie lately. The Guardian. Retrieved from

$<$ https://www.theguardian.com/commentisfree/2014/jan/25/disney-frozenreligious-allegory>

Rottenberg, L. (2014, October 28). Walt disney created his most famous character in a fit of rage. Business Insider. Retrieved from $<$ http://www.businessinsider.com/walt-disney-created-mickey-mouse-in-anger2014 10/?IR=T> 